\title{
RESENHA
}

\section{FORMAÇÃO DOCENTE PARA A EDUCAÇÃO INFANTIL: EXPERIÊNCIAS EM CURSO}

\author{
Vivian Iwamoto $^{1 *}$
}

Sarat, Magda; Troquez, Marta Coelho Castro; Silva, Thaise da. (org.) Formação Docente para a Educação Infantil: experiências em curso. Dourados-MS: Ed. Universidade Federal da Grande Dourados, 2018. 252 p.

As discussões sobre as infâncias e as crianças empreendidas no campo temático da formação inicial e continuada de professores foram incorporadas na Coletânea Formação Docente para a Educação Infantil: experiências em curso, organizada pelas professoras pesquisadoras Magda Sarat, Marta Coelho Castro Troquez e Thaise da Silva. As autoras apresentaram 14 capítulos elaborados por docentes de distintas áreas em conjunto com formadores, orientadores e discentes da Especialização em Docência na Educação Infantil, oferecido pela Faculdade de Educação (FAED) da Universidade Federal da Grande Dourados (UFGD), na cidade de Dourados, Mato Grosso do Sul, ocorrido em outubro de 2014 a abril de 2016.

Com a formação de 47 docentes, a coletânea demonstra o resultado do envolvimento, das reflexões e do aprofundamento no cotidiano da Educação Infantil na realidade do estado de Mato Grosso do Sul. A partir da perspectiva da construção de pedagogias descolonizadoras, por vezes, revolucionárias e de pedagogias participativas, os pressupostos da obra contempla três Eixos nesse sentido, sendo eles, Fundamentos da Educação Infantil (3 capítulos); Identidades, Diversidade Cultural e Prática Docente (5 capítulos); e Cotidiano e Organização da Ação Pedagógica (6 capítulos).

Adentrando ao conteúdo, ficou evidente que o interesse das autoras na primeira seção se integra nas evidências sobre a história, a política e a formação docente como requisitos básicos na fundamentação sobre a educação infantil pautada em novos olhares e novos conflitos, o que significa levar em consideração as especificidades, os contextos e os anseios das múltiplas infâncias com suas singularidades sociais, históricas, étnicas, familiares, de gênero, de classe social, religiosa e educacional. No quesito institucional da educação formal, o conceito de infância é compreendido como fenômeno social e as crianças são parte de uma categoria geracional e consideradas sujeitos ativos, enquanto produto e produtoras de cultura de seu lugar e de seu tempo, imbuídas de direito.

Ao longo dessa conquista histórica, a estruturação de diretrizes que organizam as instituições educacionais voltadas à criança passou a ter a incumbência do cuidar e do educar como proposta central, assim como adoção de uma gestão educacional democrática que atenda as particularidades pedagógicas das creches e pré-escolas. Isto é, um trabalho coletivo e dialógico

\footnotetext{
* Doutoranda em Educação pelo Programa de Pós-Graduação da Universidade de São Paulo (USP). Docente no Centro Universitário da Grande Dourados (UNIGRAN).
} 
que considera a profissionalização do educador, sua formação inicial e continuada. A “tia" já não faz mais parte do vocativo docente e a imagem do "superprofessor", multifuncional e polivalente se dissipa, oferecendo espaço para diferentes práticas que valorizam a diversidade cultural, principal assunto da segunda seção da Coletânea.

Destaca-se, então, a educação inclusiva baseada no princípio da igualdade de direitos e do respeito às diferenças, favorecendo o acesso, a permanência e o desenvolvimento pleno de todas as crianças, independente da etapa (educação infantil, ensino fundamental e ensino médio) e da modalidade da educação básica (educação de jovens e adultos, educação especial, educação profissional e tecnológica, educação do campo, educação escolar indígena e educação à distância).

Especificamente, a educação especial, como modalidade que se preocupa com o atendimento educacional especializado (AEE) aos alunos com deficiência, altas habilidades/superdotação e transtornos globais do desenvolvimento, na rede regular de ensino e nas Salas de Recursos Multifuncionais, ainda permanece incipiente em sua forma de atuação, quando se trata do trabalho colaborativo entre o professor da sala e o profissional especializado. Além disso, conforme o relato das autoras, denuncia-se o despreparo dos profissionais envolvidos, a falta de um trabalho em conjunto e a precariedade das condições físicas e materiais dessas instituições, condições que afetam os objetivos da inclusão escolar.

Outras questões envolvendo a educação inclusiva, está nas relações cotidianas de hierarquização e segmentação social que sustentam as desigualdades na sociedade, a exemplo, o fenótipo negro diante do signo social da pobreza e da exclusão, como marca do racismo, apontado no texto, quando crianças negras são interditadas do direito do cuidado, do afeto, do paparico, do acesso aos bens econômicos, simbólicos e culturais na educação infantil. Violência muitas vezes velada, em detrimento da imposição do padrão eurocêntrico e do terrorismo colonial, legitimados pelas relações de poder. Por isso, há uma necessidade de desconstruir a subalternidade prescrita e problematizar os processos de empoderamento na construção das identidades e subjetividades infantis.

Nesse sentido, o pertencimento racial constituído nos ajustes, nas negociações e nos conflitos também acontece diante das crianças indígenas. Seja Guarani, Kaiowá ou Terena, as crianças em suas culturas exercem relativa autonomia, pois estão envolvidas cotidianamente nas relações sociais e culturais do seu povo, partilhando experiências em todos os espaços da comunidade. Quase não há punições e as crianças articulam sua aprendizagem com suas responsabilidades adquiridas pela observação e experimentação no convívio com os adultos ou mais experientes. Exemplos a serem seguidos e incorporados na realidade das instituições educacionais brasileiras.

Assunto igualmente abordado dentro da educação inclusiva, foi a questão da sexualidade e da identidade de gênero na infância. Os discursos circulantes frequentemente são enfáticos no binarismo de gênero e na heteronormatividade, como se ser homem-masculino se resumisse na perspectiva biológica em ter pênis e ser mulher-feminino em ter vulva/vagina. No entendimento da autora, gênero é uma construção cultural, sem os determinantes biológicos, em que as pessoas se expressam de modos a direcionar suas masculinidades e feminilidades. Já as identidades sexuais são formas pelas quais os sujeitos se orientam ou vivem seus desejos, seja com mesmo sexo (homossexual), sexo aposto (heterossexual), ambos sexos (bissexuais), sem parceiros/as ou sem prática do ato sexual. Esses conceitos muitas vezes são confundidos entre si e engendram polêmicas que, por vezes, tornam-se discursos homofóbicos por subentender ser desviante do "normal”. Da mesma maneira, há um equívoco na ideia de que a criança é atemporal, universal, 
passiva, sem sexualidade, sem gênero, sem pensamento, sem voz, sem direitos. Nos estudos demonstrados, a criança expressa sua sexualidade como forma de comunicação no ensejo de saber sobre seu corpo, sua vida e sua existência.

No intuito de atender essas necessidades infantis e respeitar as diferenças, o currículo, o cotidiano e a organização pedagógica precisam estar em sintonia, assegurando o espaço e o tempo na instituição de educação infantil e suas diversas linguagens, incluindo o brincar. Na terceira seção fica evidente a importância da valorização das múltiplas experiências, como a escrita, a arte, a natureza, os jogos, enfim, todas as abrangências do rigor interdisciplinar nos espaços de convívio com as crianças.

O jogo educativo, preservado no equilíbrio entre sua função lúdica e sua função educativa, sem dúvida, colabora na aprendizagem da criança, amplia seu repertório comunicativo, alarga suas ações nos relacionamentos sociais, experimenta novos papeis, cria, transforma, confronta, negocia e compreende. O brincar infantil pode ser reprodutivo ou criador, cuja ação acontece pela memória ou por novas combinações de uma atividade imaginativa, sempre dialogando com as vivências sociais e com as condições da realidade cultural. Sendo assim, o brincar sempre aprendido socialmente, pode ser mediado pelo professor para alcançar seu potencial educativo, não ocupando um lugar secundário, deslocado do cotidiano infantil, mas como parte do planejamento e na base de todas as atividades pertencentes às crianças.

Acontece da mesma maneira com o universo da escrita e da leitura, por meio de um viés lúdico, segundo as autoras, não existe uma definição para qual melhor idade ou melhor metodologia na alfabetização de crianças, apenas se oferece respostas à altura de suas necessidades e curiosidades, estabelecendo relações entre a oralidade e as formas de registro. Outras linguagens (teatro, cinema, música, artes visuais, literatura, poesia, danças) e suas possibilidades sensibilizadoras (visual, auditivo, gestual, motor, cinestésico) ampliam a percepção, a expressão e a apreciação dos diferentes mundos que os cercam. A obra enfatiza essa importância da arte e até mesmo temas como ecologia e discussões sobre os problemas ambientais, a organização dos ecossistemas, o cuidado com plantas e animais que geram atitudes norteadoras aos pequeninos.

A coletânea encerra com a análise do compilado de pesquisas, dos trabalhos de conclusão de curso, realizados pelos discentes da especialização em questão, os quais 47 diferentes eixos temáticos relevantes foram contemplados, demonstrando a riqueza e a diversidade no cotidiano da educação da infância. Nesse contexto, fica evidente a responsabilidade e a ética das pesquisas com as crianças e a necessidade de mais cursos de formação continuada aos professores da educação infantil, os quais, na oportunidade, possam repensar suas práticas, refletir, problematizar, descontruir estigmas e aprimorar as condutas no intuito de compreender as complexidades infantis e fazer com que essas investigações reverberem no cotidiano das práticas educativas, tendo o professor pesquisador e a criança no centro das experiências em curso.

Recebido em: 23/05/2019

Aprovado em: 26/07/2019 